information under this head afforded by the present publication has been common knowledge amongst all those interested for so long that it no longer presents any features capable of attracting attention.

The most interesting portion of the present report is accordingly that portion that deals with the labour employed in the world's mineral industry. It is shown that the number of persons engaged in this industry exceeded $6 \frac{1}{2}$ millions, more than one-third of whom were employed in the British Empire. It is interesting to note that more than one-half of this number was employed in coal mining, and as coal mining in different countries is more readily comparable than any other class of mining, because the conditions under which it is carried on present closer points of agreement, it may be profitable to compare briefly the labour statistics. Out of a total production of $\mathrm{I}, 250,000,000$ metric tons of coal in the whole world, Great Britain alone produces $264,600,000$ tons and the whole British Empire 314,500,000 tons, or about a quarter of the whole output. The other large producers are the United States with 484,900,000 metric tons; the German Empire, 255,800,000; AustriaHungary, 5I,700,000; France, 4I, 100,000; Russia, 31,300,000; Belgium, 23,000,000; and Japan, $19,700,000$. It is curious to note that, with the exception of the United States, this list includes all the important nations engaged in the present war. The producing capacity of the miners engaged in this industry in metric tons per worker per annum is shown in the following table:-

\begin{tabular}{llll|llll} 
Great Britain & $\ldots$ & 230 & United & States & $\ldots$ & 671 \\
Australia & $\ldots$ & $\ldots$ & 535 & German & Empire... & 272 \\
Canada & $\ldots$ & $\ldots$ & 486 & Austria & $\ldots$ & $\ldots$ & 307 \\
India & $\ldots$ & $\ldots$ & 129 & France & $\ldots$ & $\ldots$ & 307 \\
New Zealand & $\ldots$ & 51 & Russia & $\ldots$ & $\ldots$ & I42 \\
South Africa & $\ldots$ & 347 & Belgium & $\ldots$ & $\ldots$ & I57 \\
Japan & $\ldots$ & $\ldots$ & 129
\end{tabular}

It will be seen that with the exception of India, where the labour is almost exclusively native, no part of the British Empire can show so low an output per head as does Great Britain itself, whilst of foreign countries it is only the smaller producers that rank worse than ourselves. In part, this small production is no doubt due to the fact that so many of our thicker and more easily wrought seams are to a large extent worked out, and that we are therefore compelled to work the thinner seams, from which a smaller output per man is necessarily produced. This drawback should, however, hive been largely offset by the use of mechanical means for cutting and transporting coal, and it is difficult to avoid the conclusion that the low output is due to the restrictive policy covertly, if not overtly, encouraged by the Trades Unions.

It is some satisfaction to find that British coal mining is conducted with a great regard for the safety of the men engaged in this occupation. The deathrate per thousand workers employed is given as follows :-

\begin{tabular}{|c|c|c|c|c|}
\hline Great Britain & & Fr: & & \\
\hline British Empire & $x \cdot 24$ & Russia & $\cdots$ & \\
\hline United States & 3.26 & Belgium & $\cdots$ & $\cdots$ \\
\hline ire & $\begin{array}{l}2.44 \\
1.48\end{array}$ & Japan & $\ldots$ & \\
\hline
\end{tabular}

If the death-rate be compared, not per worker but per million tons of output, Great Britain will not appear in quite so highly favourable a light as compared with the United States, for example, that of the former being 4.66 deaths per million metric tons, and of the latter 5.44 . N svertheless, from every point of view our standard of safety may be looked upon as high.

$$
\text { NO. } 237 \text { I, VOL. 95] }
$$

It ought to be added that the above statements are calculated from the data tabulated in the report in question, which gives the figures for the various countries as though they were obtained in the same way, and therefore strictly comparable, which is far from actually being the case. Different countries use different methods of determining their mineral production, the number of men engaged in the industry and the number of deaths due to it, and the figures given are not therefore strictly comparable, though they may be expected to give a rough standard of comparison. One of the objects aimed at for many years by statisticians interested in mineral production was to get an international understanding as to the basis on which all these figures were to be determined, but now that Germany has in a few months destroyed the work of many years of European civilisation, and by her own relapse into barbarism has dragged all other nations down with her, any prospect of agreement on such minor international questions appears to be quite hopeless.

H. L.

\section{REPRODUCTION AND HEREDITY.}

PROF. J. A. DETLEFSEN (University of Illinois) has made an important contribution to our knowledge of "Mendelian" inheritance by his "Genetic Studies on a Cavy Species Cross" (Carnegie Institution, Publication No. 205, I914). The research -begun by Prof. W. E. Castle-is of interest as affording information from the crossing of two distinct species, for the wild Brazilian cavy (Cavia rufescens) is apparently sharply distinct from the common domestic guinea-pig ( $c$. porcellus). The sterility of hybrid animals is known to be a rule admitting of many exceptions. In the experiments with cavies here described, crosses between $C$. rufescens males and $C$. porcellus females gave completely sterile male and fertile female hybrids. By mating the female hybrids with porcellus males, quarter-wild hybrids were obtained, again sterile males and fertile females; but by repeated back-crosses of female hybrids to porcellus males, individuals with increasing fertility were obtained. "Fertility seemed to act like a very complex recessive character; for the results obtained were what one would expect if a number of dominant factors for sterility were involved, the elimination of which would give a recessive fertile type." The paper is noteworthy because skeletal characters of the parents and hybrids are figured and com. pared, in addition to the usual external features, such as coat-colour.

A case of sex-limited inheritance in plants is discussed by Mr. G. H. Shull, who has made crosses between the typical Lychnis dioica and its variety angustifolia (Zeitschr f. indukt. Abstammungs $u$. Vererbungslehre, xii., 5, I9I4). The narrow-leafed form is a recessive which reappears in half the males of the $\mathrm{F}_{2}$ generation. All the $\mathrm{F}_{2}$ broad-leafed males are heterozygous for the broad-leaf factor, while of the females half are heterozygous, half homozygous for this factor. As regards sex, the female Lychnis is a homozygote and the male a heterozygote.

Dr. Raymond Pearl continues his observations on the reproductive organs of domestic fowls. In a paper on the effects of "Ligation, Section, or Removal of the Oviduct" (Journ. Exper. Zoo., xvii., 3, I9I4), he states that these operations have no injurious effect on the growth of the ovary, and that after removal or closing of the oviducal funnel, eggs are passed into the body-cavity, where, if not absorbed at the peritoneal surface, they may cause "serious metabolic disturbances." In the Journ. Biol. Chemistry (xix., 2, 1914) Dr. Pearl informs us that injection of the 
desiccated fat-free substances of a cow's corpus luteum into a laying fowl at once inhibits ovulation. The possible practical importance of studies in heredity is shown by a short pamphlet from the annual report of the Maine Agricultural Experiment Station for I914 on improving, egg-production by breeding, and by a Bulletin (No. Iro) of the U.S. Department of Agriculture (Bureau of Animal Industry), in which Dr. Pearl, with Dr. F. M. Surface, gives "A Biometrical Study of Egg-Production in the Domestic Fowl."

\section{BACK TO LISTER. 1}

WHEN Sir James Crichton-Browne, amongst whose many charms is a singular félicity of phraseology, invited me to undertake this task, he kindly supplied the title. It sounded rather startling, but as I could not think of a better, I humbly accepted it. It shows that I have no great discovery to announce, no new theory to propound, but only to take you back over old, well-trodden ground, to try to interest you in very technical matters, and to suggest that, in this particular case, reaction has overstepped the bounds of moderation, and that, as in many other fields, the most modern ideas are not always the best.

I will not trace the various steps by which Lister was led to his conclusions about the causes of suppuration and hospital diseases, nor draw a lurid picture of the deplorable mortality from these diseases before the introduction of the antiseptic system of treatment. I must, however, give you a short account of his first antiseptic method, which was founded on the discoveries of Pasteur, and explain in what way and for what reasons he afterwards modified it. If I succeed in making this clear it will be easy to understand how the relinquishment of much that he at first considered essential, but which later discoveries proved to be superfluous, led others to give up still more -much more than he ever considered it prudent to do. It will then be maintained that what he feared has come true: that the results obtained to-day, good though they are, are not so good as they would be if we were to return, perhaps not altogether, but almost, to those simpler and safer methods which Lister employed at the end of his active career.

Let us begin by trying to place ourselves in Lister's position during the years preceding 1865 , when the writings of Pasteur were first brought to his notice. It was that of every thoughtful surgeon in those days. Of all the dealings of Providence with men-remember I am speaking of sixty years ago-not the least mysterious appeared to be the ordinance that the lifegiving air, heaven's blessed breeze, without which life cannot be maintained for more than a few minutes, and on the purity of which man's vigour depends, should carry in some unexplained way the seeds of death and disease, being one day the doctor's greatest friend and the next his deadliest foe.

Physicians were quite sure that the acute specific fevers, such as scarlet fever and measles, were carried on the wings of the wind, and few had any doubt that cholera was borne by the same vehicle. Surgeons were equally certain that erysipelas should be placed in the same class as the acute specific fevers and that the suppuration of wounds depended upon the same agency. It seemed quite obvious, to anyone who thought about the difference in the behaviour of simple and compound fractures, that is, fractures with unbroken skin and those which are complicated by the presence of a wound. Except for this complication the fractures might be identical, but, in pre-antiseptic 1 Disconrse delivered at the Royal Institution on Friday, March Iz, by Sir R. J. Godlee, Bart., K.C.V.O.

$$
\text { NO. } 237 \mathrm{I} \text {, VOL. 95] }
$$

days, the presence of a wound was almost certain to lead to suppuration of a serious, if not a dangerous nature.

Old Glasgow students speak of Lister contemplating a simple fracture of the leg; the muscles torn and pulped, the limb swollen and shiny, black and blue, and pointing out to them that all this destruction of tissue and extravasation of blood would be surely and safely dealt with by the kindly influences of nature; but that the admission of the air through the smallest wound in the skin would completely change the prospect; the extravasated blood would soon stink, the injured tissues--bone and muscle-would die, and suppuration would take place, which might possibly infect the whole system. It did not enter into the mind of anyone, therefore, to doubt the morbific influence of the air. It was one of those things which appear so obvious that for a time they form the very foundations of belief, such as that the earth is flat and that the sun rises, matters which in more barbarous times laid sceptics open to the rigours of the Inquisition.

This was still the universal belief when Pasteur's discoveries were made known. Pasteur put the finishing touch to the work of many observers, who, during the first half of the last century, had been striving to find out what there was in the atmosphere which gave rise to fermentations of all sorts, and amongst others to that form of fermentation known as putrefaction. So long as fermentation and putrefaction were looked upon as chemical processes it was natural to suppose that one of the gaseous constituents of the air was the cause. But clear thinkers, like John Hunter, saw that this could not be the case.

There are two surgical conditions that prove this:-

(I) If a rib be broken and a sharp fragment injures the lung, large quantities of air may pass from the lung into the pleural cavity, but if the lung be healthy, decomposition never occurs in the putrescible fluid that is always present in the pleura in small quantity.

(2) If air passes into the cellular tissue of the body, as it sometimes does after the same accident, or some other injury of the air passages, large portions of the body may be distended by it to an extent that appears alarming. But again, as the air is effectually filtered on the way, decomposition does not occur and the evil result is only a temporary mechanical one.

Investigators, therefore, began to think that the cause of fermentation must be something solid and possibly living; something so small that it eluded their highest magnifying glasses, and so they adopted different lines of attack

Some calcined the air, some filtered it, some passed it through causic fluids: There was an old French confectioner named Appert-Citoyen Appert, in the time of the Republic, who anticipated by many years the work of our modern fruit preservers. He succeeded in preserving all sorts of food in well-corked bottles by boiling them for various lengths of time according to the particular article he was dealing with; and his results were so nearly uniform and so remarkable, from an economic as well as from a scientific point of view, that they attracted the attention of the French Minister of the Interior in I8Io, and also of the Académie Française.

Unscientific as these observations were, they gave an impetus to the work of chemists and biologists who carried out an enormous number of really scientific investigations in consequence. These were repeated by Pasteur, who made countless others of his own, of marvellous ingenuity. The results of his labours in this particular field before $186_{5}$ may be given in a tabular form. He showed that :-

(I) Putrefaction is a species of fermentation. 